\title{
Teologiese opleiding tydens die Reformasie
}

\author{
H R Balzer \\ Lutherse Teologiese Seminarie, Pretoria
}

\begin{abstract}
Theological training during the Reformation

The profound changes in theological education during and after the Reformation are interpreted in the light of the new soteriology of Martin Luther, Philipp Melanchthon, and their followers. A comparison with the humanistic movement reveals the specifically theological character of education in that time. Salvation was no longer directly administered by the church, but communicated through the study of the Bible as witness. Finally, the article points to the importance of the heritage of this movement for theological education in today's cultural and religious situation.
\end{abstract}

\section{DIE SOTERIOIOCIFSE VERTREKPUNT}

Die onderwerp van hierdie artikel is alles behalwe nuut. In die lig van die breë en diepgaande invloed wat die Reformasie tot vandag toe oor die breë spektrum van die kultuurlewe uitoefen, is daar waarskynlik meer navorsing daaroor gedoen as oor enige andere historiese gebeurtenis in verband met teologiese opleiding. As gevolg van die ingewikkelde historiese verbande wat daaraan ten grondslag lê, word die Reformasie en sy uitwerking vanuit verskillende godsdienstige, sielkundige. sosiologiese, politieke, kultuurhistoriese en ander perspektiewe beskryf. Elkeen van hierdie perspektiewe beklemtoon bepaalde fasette en aspekte en dra sodoende by tot 'n outentieke totaalbeeld.

- V(xordrag gelewer tydens die kongres van 18 en 19 Junic 1992 in dic Senaatsaal, Universiteil van Pretoria met die tema 'Kerklik-lculoglese opteiding aan dic Universitcit', let herdenking van die uyf en sewentigste hestaansjaar van dic Fakulteit Teologic (Afd A) aan dic Linicersitcil van Pretoria. [Dt Batect is sedert 1993 nie meer verhonde aan dic Lutherse Teologiese Semınaric nic - Redakleur.) 
Die Reformatore en hulle volgelinge was volgens hulle eie aanspraak suiwer teologies gemotiveer. Moderne navorsers daarteenoor, is dikwels geneig om die godsdienstige agtergrond van die Reformasie eeruer sekondêre prioriteit te gee teenoor ander motiewe soos politieke, ekonomiese en materiële belange. Van die meer as sewentig biografiese boeke, wat tussen 1982 en 1985 in Duitsland verskyn het, was daar volgens ' $n$ interne ondersoek deur die Koordinierungsausschuss zum Lutherjahr 1983 omtrent vyftig boeke in die eerste plek sosiologies en polities van aard. So byvoorbeeld word die verryking van owerhede deur die konfiskering van die voormalige kloosters se besittings tot 'n primêre motief verhef, en die godsdiens eerder as 'n soort verskoning beskou. Dié heersers het volgens hierdie standpunt die Reformasie aanvaar juis omdat dit hulle verryk het. Die feit dat hierdie konfiskering eerder ' $n$ uitsondering was, en dat die Reformasie vanweë die gepaardgaande hervorming van skole en universiteite baie duur geword het vir die owerhede, word dan gewoonlik uit die oog verloor. Nog vandag word dié fondse deur onafhanklike organisasies soos die Klosterkammer Hannover geadministreer (Cam. penhausen 1983:25).

Sulke veronderstellings berus klaarblyklik op 'n onuitgesproke siening van die huidige tyd wat meestal onbewus op die Reformasie toegepas word. Daar word naamlik sedert die sogenaamde Verligting (Aufklärung) glo besonder realisties gedink. Realisties beteken hier dink in terme van eie voordele soos mag en geld. Godsdienstige belange, wat nie in hierdie kategorieë inpas nie, word maklik as irrusioneel of selfs as propaganda afgemaak. Daar is al so aan die sekondère gebruik of eerder misbruik van godsdienstige gesag gewoond geraak, dat daaragter gewoonlik ' $n$ ander, verborge bedoeling vermoed word. Indien religie dan buite die eie kulturele konteks wel 'n primère politieke of kulturele dryfkrag word, soos in die geval van die revolusie in Iran, is daar die neiging om dit gou as fanatisme, irrasioneel en so meer af te wys.

Hierdie siening kyk die interessante feit mis dat hierdie eeu waarskynlik meer deur ideologieë en totaal irrasionele motiewe gekenmerk word as enige ander tyd tevore. Indien daar dus die bereidheid is om ideologieë as primère motiewe te aanvaar, hoekom dan nie godsdienstige beweegredes ook vir 'n tyd waar die vraag na die heil van die mens inderdaad primèr op godsdienstige vlak gevra is nie? Met ander woorde: Hoekom sou dit vir 'n mens of selfs 'n heerser tydens die Reformasie eo ipse van groter belang wees om ryk en magtig te word, as om hemel toe te gaan? Die tendens om alhei sake soveel as moontlik harmonies te verbind, maak daaraan in beginsel nie 'n verskil nie: Natuurlik is dit lekker om later hemel toe te gaan én tevore buitendien nog ryk en magtig te wees! 
Die beroemde erkenntnisleitende Interesse, die vraag cui bono?, is slegs geldig vir sover dit die outentieke historiese waardes in ag neem en nie moderne voorkeure en waardes as maatstaaf gebruik nie.

Teen hierdie algemene verstaan en moderne sin, sal nou gepoog word om opleiding tydens die Reformasie vanuit sy eie godsdienstige aanspraak te interpreteer, en om ander verbandhoudende sake onk uit hierdie perspektief te verstaan.

Die Reformatoriese teologie het in die eerste plek na vore getree as ' $n$ totaal nuwe begrip van hoe God se heil aan die mense bemiddel word. Die hoeksteen van Luther se teologie is die particula exclusiva, waarvolgens die heil alleen uit genade. alleen deur Jesus Christus, alleen deur middel van die Skrif en alleen deur die geloof toeganklik is. Om presies te wees moet ons in verband met die Reformasie eintlik primèr van 'n soteriologiese beweging praat. Die Reformatore was met'n nuwe teologie gerig op dié heil, wat die destydse Rooms-Katolicke Kerk nie meer geloofwaardig kon bemiddel nie.

Daar sal in hierdie artikel gepoog word om sommige van die belangrikste inherente en historiese verbintenisse tussen Reformatoriese soteriologie en teologiese opleiding aan te dui. Die grondvraag kan dan soos volg geformuleer word: Watter verband is daar tussen die teologiese opleiding, soos dit onder die invloed van die Reformasie dramaties verander en uitgebrei het, en die soteriologiese aanspraak van die Reformatoriese teologie? Omdat die hervorming van teologiese opleiding reeds aan die begin van die Reformasie plaasgevind en later nie wesenlik verander het nie, sal ons op die tyd voor 1530 konsentreer. Dit kan - pars pro toto - aan die hand van die werk van veral twee Reformatore nagegaan word: Martin Luther en Philipp Melanchthon. Albei het die hervorming van die opleiding onmiddellik aan die van die kerk gekoppel, en groot getalle skole asook universiteite gestig of hervorm. Tegelyk verteenwoordig hulle soms baie uiteenlopende fasette van teologie en verbandhoudende teologiese opleiding wat later op die geskiedenis ingewerk het. Die Reformatore wat hulle gevolg het, kon op hierdie werk. weliswaar met belangrike aanpassings, voortbou.

\section{DIE SOTERIOLOGIESE KRISIS IN DIE ROOMS-KATOLIEKE OPLIIDING}

Kultuur en teologie is in die Renaissance beheer deur die skolastiese wetenskap. Dit het baie gesofistikeerde wetenskapsteoretiese metodes ontwikkel en sodoende eintlik die wetenskaplikheid van die teologie in die Weste gegrondves en op 'n universele vlak geplaas. Dáárby het die Reformasie, al was dit ook gewoonlik sub contrurio, in 'n groot mate aangeknoop. Die skool- en universiteitswèreld was reeds goed ontwikkel en van die hegin af heeltemal Christelik. Die eerste universiteite. 
byvoorbeeld in Bologna en Parys, het hulle regte tot promosie van die pous ontvang. Teoloë soos Anselmus van Canterbury en Thomas van Aquino het die antieke wysheid, veral die metodologie van Aristoteles, ten volle in die Christelike wêreldbeskouing geïntegreer en sodoende ' $n$ indrukwekkende en alles omvattende godsdienstige wêreldbeskouing geskep.

Tog het dié hoogstaande wetenskap en die uitstekende rol wat die kloosters in die opleiding gespeel het, relatief min invloed uitgeoefen op die opleiding van die priesters en predikers op gemeentevlak en selfs op die opleiding van biskoppe en ander kerkleiers. Selfs die pous was gewoonlik eerder 'n regsgeleerde as ' $n$ teoloog. omdat sy amp eerder polities as spesifiek teologies van aard was.

Hierdie feite hou direk verband met die soteriologiese verwagtinge wat aan die priesterlike amp verbind is. Die (godsdienstige) heil van die mens is deurgaans deur die sleutelamp van die Rooms-Katolieke Kerk bemiddel. Om by hierdie kerk in te skakel en sy vereistes so ver as moontlik na te kom, was gevolglik die enigste pad na die hemel toe. Die opleiding van priesters en amptenare het daarby aangepas. Die priester was dus die bemiddelaar van die genade van die Here wat deur die kerk geadministreer is, en dit was eintlik nie nodig dat hulle teologies opgelei moes wees nie. Dit is die rede waarom byvoorbeeld die Bybel gewoonlik minder bestudeer is as die kerkvaders of die kerkleer. Die amp is hoofsaaklik op 'n kultiese manier in die heilige Nagmaal, waaraan die gemeente nie aktief deelgeneem het nie, uitgeoefen.

Die kerk het wel die middel gehad om vir die gewone mense in 'n mate gemoedsrus te gee. Dit was egter direk afhanklik van die morele en geestelike gesag wat die kerk geniet het. In die praktyk het die sleutelamp nooit volkome ex opere operato gewerk nie. Juis die gerusstellende aspek van die kerk as bemiddelaar van die heil was reeds vir meer as twee eeue vón die Reformasie besig om te verbrokkel. Dit was as gevolg van tallose misbruike binne die kerk soos korrupsie, politieke inmenging tot eie voordeel; die sogenaamde pous-skisma (1378-1415), die groot finansiële laste wat op lidmate gelè is deur kerklike amptenare en die gedrag van baie priesters en monnike. Laasgenoemde word onder meer geillustreer in verband met die hervorming van kloosters deur Nicolaus Cusanus in die jaar 1452. Sy beroep op 'n kloosterlike vita contemplativa moet teen die agtergrond van onbeheerde ontug en wilde bedrywighede in talle kloosters gesien word (Kühn 1988:474-477). Die kerk het uiteindelik nie meer aan die eie maatstawwe voldoen nie. Die sogenaamde aflaatbriewe was eintlik ook volgens destydse kerklike kritici 'n misbruik, maar dit was as sodanig nie a priori teologies onaanvaarbaar nie. Die bemiddeling van die genade en heil was wél die taak van die kerk en daarvoor moes net soos vir enige ander diens betaal word. Die probleem was die misbruik, nie die bestaan van hierdie instelling nie. 
Die aan die wantroue teenoor die kerk gekoppelde algemene soteriologiese onsekerheid het in die Middeleeve in talle uitwasse, spiritualistiese en utopiese bewegings, maar veral ook akademiese kritiek, tot uitdrukking gekom. Die beroemde vraag van Luther: 'Wie bekomme ich einen gnädigen Gott?' was destyds klaarblyklik dié vraag van die bevolking in die algemeen. Luther het dit eintlik net geformuleer en met dit as vertrekkpunt die Bybel in 'n radikaal nuwe lig begin lees.

\section{HERVORMING VAN OPLEIDING BINNE DIE ROOMS-KATOLIEKE KERKLEER}

Reeds lank voordat Luther sy teologie ontwikkel het, het leidende akademici 'n oplossing binne die kerk se soteriologiese benadering begin soek. Sonder om die soteriologie van die kerk in beginsel aan te tas, kon dit logies slegs die hervorming van die bestaande kerk met betrekking tot hoof en ledemate wees. Hierdie pad is veral deur die sogenaamde humaniste gekies wat voorbereidend en soms begeleidend veral akademiese toerusting vir die Reformasie verskaf het. Die toonaangewende sogenaamde Duitse humaniste het die nalatenskap van die Italiaanse humanisme, wat op die verbetering van die mens met behulp van die klassieke literatuur gemik was, verbind met die Middeleeuse mistiek, soos dit in die beweging van die devotio moderna ter hervorming van die kloosters, gestalte gevind het (Heussi 1979:266). Die humaniste het veral deur middel van skerp kritiek en die hervorming van kloosters na" $n$ hernuwing van die kerk gestreef, om die kerk weer tot uitvoering van sy ware amp in staat te stel. Die bedoeling was dus in beginsel positief teenoor die Rooms-Katolieke Kerk se teologie.

Die humanistiese manier om 'n blywende hervorming te weeg te bring, was egter om mense se gesindheid te verander deur middel van opleiding. Dit is nie toevallig nie dat die humanis Melanchthon sy eerste lesing as dosent aan die Universiteit Wittenberg in Augustus 1518 soos volg betitel: Oor die verbetering van die studies van die jeug (Meinhold 1960:13). Daarin bepleit hy 'n omvattende opleiding, veral in die klassieke tale, maar ook 'n verpligte studium generale. Laasgenoemde sou veral die eloquens, dit is die kuns om logies te argumenteer, antieke tale en filosofie behels. Ook Luther was reeds voor die Reformasie by die hervorming van universiteite betrokine.

Vir die humanisme was die Christendom verteenwoordigend van die een menslike godsdiens wat in beginsel ook in die antieke filosofie en ander godsdienste deurskyn. Die humaniste het geglo dat die mens deur middel van akademiese opleiding sy oorspronklike aard en bestemming kon terugvind. Humanisties opgeleide mense was veronderstel om die kerk van binne af te vernuwe. 'n Tipiese voorbeeld vind ons in Melanchthon se reaksie op die revolusie van die boere. Hy wou die 
probleem nog in die jaar 1525 deur die vestiging van verpligte skoolopleiding oplos, want behoorlik opgeleide mense sou volgens hom nooit 'n bloedige revolusie voorstaan nie. Hy het selfs geëis dat die kerk se goedere beskikbaar gestel en gebruik moes word om hierdie saak te finansier (Meinhold 1960:38).

Met hierdie ideaal is aan menslike opleiding ' $n$ sentrale rol en inherente waarde toegeken. Die hervorming van die kerk as bemiddelaar van die menslike heil begin in die skole, nie by die preekstoel nie. By 'n geleentheid het die jong Melanchthon in Duits uitgeroep: 'Die Zunge soll man denen abschneiden, die zugunsten der Predigten die unkundige Jugend allenthalben vom Studium der Wissenschaften abhalten' (Meinhold 1960:43). Hy het talle universiteite gestig, hulle orde gereël asook opvoedkundige boeke gepubliseer en in sy eie huis vir baie jare 'n schola privata bedryf (Meinhold 1960:40).

Melanchthon self stel ook 'n goeie voorbeeld vir die ideaal van 'n omvattende studium generale. Hy het onder meer geneeskunde, wiskunde, regte en veral astrologie (wat in daardie tyd as natuurwetenskap sonder enige bygelowige element beskou is) akademies beoefen en toe al hierdie studies met dié van die teologie afgesluit en bekroon. Alle wetenskappe is volgens hom diensmaagde van die teologie (Meinhold 1960: 12).

As maatstaf van die kritiek teen die kerklike misbruike, het die humaniste die Bybel gebruik - vandaar die slagspreuk: Ad fontes! Humaniste soos Reuchlin, 'n grootoom van Melanchthon, en Erasmus van Rotterdam, met wie Melanchthon tot die einde van sy lewe goed bevriend was, het die Hebreeuse en Griekse Bybel uitgegee.

\section{DIE REFORMASIE AS SO'TERIOLOGIFSE ALTI:RNATIIF}

Die Reformasie het wel in baie opsigte by die humanisme aangeknoop en word derhalwe dikwels as 'n kind van die humanisme beskou. Daartoe dra onder meer die feit by dat die meeste van die eerste Reformatore in 'n humanistiese akademiese klimaat grootgeword en gevolglik humanistiese terminologie en denkpatrone gebruik het. Hierdie formele aansluiting by die humanisme lei egter maklik daartoe dat die radikale en diepgaande teologiese verskille tussen die humanisme en die Reformatoriese teologie misgekyk word. Trouens, teologies en soteriologies gesproke was die Reformasie eerder ' $n$ teenoorstaande alternatief as ' $n$ voortsetting van die humanisme (Aland 1982:14-19). Dit het byvoorbeeld in Erasmus se stryd teen 1 uther oor die vryheid van die menslike wil duidelik geword. Luther ontken nie net die soteriologiese amp van die kerk nie, maar hy wys veral enige moontlikheid om die mens te verbeter radikaal van die hand. Sy oordeel peccarum 
originale et radicale, wat inderdaad 'n articulus stantis et fallentis in sy teologie is, maak eo ipse enige verbetering van die mens, ook deur middel van opleiding, onmoontlik.

Ook die sukses van die Rooms-Katolieke contra-Reformasie werp lig op die verhouding tussen Reformasie en humanistiese protes. Nadat die kerklike misbruike grotendeels uitgeskakel is, het groot gedeeltes van Europa na die Rooms-Katolieke Kerk teruggekeer, soos byvoorbeeld Pole en die Suide van Duitsland. In hierdie gebiede was die invoering van die Reformasie klaarblyklik humanisties gemotiveer. In gebiede waar die Reformasie deur Lutherse en Calvinistiese teologiese opleiding gevestig is, het dit egter glad nie gebeur nie (vgl Aland 1982:15). Erasmus byvoorbeeld het as humanis die Reformasie onmiddellik afgewys toe hy die ware teologiese verskille raakgesien het. Daarenteen het Melanchthon se oorspronklike humanistiese gesindheid tydens die Reformasie aansienlik verbrokkel (Meinhold 1960:15-17).

Teenoor die humanisme het die Reformasie die behoefte na beter opleiding, wat destyds algemeen geëis is, uit die teologiese karakter van die kerkamp, en nie uit menslike waardes nie, afgelei. Die predikant moes die heil deur die verkondiging van God se woord van genade aan die mense bemiddel, en vir hierdie taak moes hy die Skrif vir die gemeentes ontsluit. Die bestudering van die Bybel verkry daarmee indirek soteriologiese betekenis.

Die beginsel sola Scriptura was vir Luther nie soos vir die humaniste 'n maatstaf ter verbetering van die kerk nie, maar 'n soteriologiese en selfs eskatologiese uitspraak. Die soteriologiese betekenis van die kerk word, om dit 'n bietjie te vereenvoudig, deur die gesag van die Bybel as getuienis van die ecclesia primitiva vervang. Dit is nie toevallig nie dat Luther (1519:1610) reeds in sy skrif Vom Studiren (sic) der Priester voorstel dat elke predikant, voordat hy gaan slaap, een of meer Bybelverse moet lees. Die humanistiese slagspreuk ad fontes verkry gevolglik ook 'n nuwe motivering, naamlik die bemiddeling van die heil aan die mens in plaas van die hervorming van die kerk met die Bybel as maatstaaf. Die kerk word ecclesia invisibile, omdat dit nie meer direk deur die administrasie van sy ampte nie, maar deur die hantering van Woord en sakrament die heil bemiddel (Confessio Augustana VII). Die sola Scriptura skep ook 'n kritiese afstand teenoor die tradisie van die kerk. Luther beveel in sy lesings oor die Psalms wel nog die bestudering van die kerkvaders aan, maar hy doen dit met verwysing na 1 Tessalonisense 5:21: 'Toets dit alles en behou wat goed is' (Luther 1521:666). Die Reformatoriese sola fidei het eweneens die vroeëre primère soteriologiese funksie van die kerkamp uitgeskakel. Ook die ander particula exclusiva, soos solus Christus, verwys die mens na die getuienis in die Skrif, waarsonder ons niks van Christus kan weet nie. 
Tog word daar ook nie aan die Bybel 'n onmiddellik-soteriologiese funksie toegeken nie. Met betrekking tot die Lutherse teenoorstelling van wet en evangelie en daarmee saam die satisfactio peccatorum (dit wil sê sy soteriologie in geheel!) word die teologiese en soteriologiese homogeniteit van die Bybel bevraagteken (vgl Peters 1981:30-57). Hierdie kritiese hermeneutiese beginsel het dit onder meer vir Luther moontlik geınaak om Bybelboeke soos Jakobus en die Hebreërbrief te bevraagteken of eintlik te verwerp. Hy beklemtoon in sy kommentaar op Genesis dat die kennis van Bybelse tale nutteloos is sonder die kennis van die saak, dit wil sê die hele Bybelse boodskap (Luther 1536-1545:322).

Tog was dit aan die begin van die Reformasie nie realisties om akademiese opleiding vir alle predikante as 'n vereiste te stel nie. Luther het dit ook nie nodig geag nie. So skryf hy in die Sermon, dass man die Kinder zur Schule halten soll uit die jaar 1530:

Denn man bedarf nicht allein hochgelehrter Doktoren und Magister in der Schrift, man muss auch gemeine Pfarrherren haben, die das Evangelium und Katechismus treiben im jungen und groben Volk, taufen und Sakrament reichen etc. Ob sie nicht zum Streit wieder die Ketzer taugen, da liegt nicht Macht an; man muss zum guten Gebäude nicht allein Werkstücke, sondern auch Füllsteine haben....

\section{(Walch X 1892:434)}

Die gewone predikant het slegs 'n basiese kennis van die Bybel en die Kategismus nodig gehad, terwyl die teoloog as selfstandige eksegeet van die Skrif, maar veral as apologeet teen kettery 'n volle akademiese opleiding, waarby filosofie en klassieke tale ingesluit is, moes deurloop.

\section{NUWE VERWAGTINGE AAN TEOLOGIESE OPLEIDING}

Feitlik alle Duitse universiteite is of tydens die Reformasie gestig of in die lig van die Reformasie geheel en al hervorm.

Die bemiddeling van die Woord van God geskied uit die aard van die saak nie ex opere operato nie. Slegs 'n goed opgeleide predikant kan sy hoorders met die Bybelse boodskap van God se genade konfronteer. Gevolglik word die priester van die kerk nou 'n predikant van die Woord van God. Die verstaan van die sakramente het eweneens verander - by Calvyn en Melanchthon meer as by Luther.

Dit is maklik om te verstaan watter kennis en akademiese bekwaamhede daarmee in beginsel van die predikante geëis is. Hulle moes feitlik die hele Bybel nie net leer nie, maar dit veral korrek en duidelik interpreteer om sodoende die heil aan die mense te verkondig. 
Luther (1529a:502) het die skerp kontras tussen die vereistes wat aan predikante gestel word in verglyking met die Rooms-Katolieke Kerk, asook die probleme daaraan verbonde in sy praefatio van die Klein Kategismus soos volg beskryf:

Hoc igitur probe considerent parachi et ministri longe jam aluid esse officium, quam olim in papatu fuerit. Jam enim est ministerium salutis et gratiae, fit igitur, ut quoque dificilius sit et laboriosus. Et cum gravissima pericula et tentationes in eo ministerio sint perferendae, tamen neque laborum praemium neque gratias in mundo meretur.

In dieselfde geskrif sê hy met betrekking tot die priesters: 'Nihil omnio a bestiis differunt' (Luther 1529b:507). En in verband met skoolhervorming sê hy in Duits: 'Und in summa, ein Priester hat geheissen, der Messe halten könne, obgleich er nicht ein Wort hat wissen zu predigen und ein ungelehrter Esel gewesen ist....' (Luther 1530:425). Die meeste van die priesters kon, soos dit blyk uit verslae van die tyd oor visitationes, gewoonlik nie eers die Onse Vader of die Tien Gebooie opsè nie. Luther (1529b:502) kla soos volg oor hulle: '...[S]ymbolum apostolicum et decalogum non modo non intelligant, sed ne verba quidem referre possint'. Ons kan hulle nie daarvoor blameer nie, want hulle was inderdaad vir' $n$ heeltemal ander amp toegerus. Met die Reformasie word in plaas van die kerk nou teologiese en hermeneutiese riglyne, wat wel in die verskillende Reformatoriese tradisies verskil, die gubemaculum interpretationis van die Bybel en daarmee van die geloof in sy geheel. Die teologie is volgens Luther (1521:75) die hoogste moontlike amp omdat dit diensbaar is aan die ware heil.

Daarmee word aan die teologiese opleiding in die Reformasie indirek 'n soteriologiese betekenis toegeken. Dit konsentreer op Bybelse teologie. Die studente moes daarby let op die onmiddellike verband van Bybelse uitsprake en nie te gou na die eie interpretasie oorgaan of hulle toevlug neem tot allegorieë nie (Luther 1526:694). Luther beveel aan dat biblioteke veral met Bybels, Bybelse kommentare en chronica toegerus moet word (Luther 1524:483). Sonder hierdie konsentrasie op die Bybel word universiteite volgens Luther (1520a:341) portae infemis (deure van die hel). Dit is opvallend dat die motief vir die studie van die geskiedenis die gedagte is dat die kerk deur God gelei word, en dat die geskiedenis self van God se genade getuig. Dit is klaarblyklik ook die enigste grondige rede om dit te bestudeer! Ook in hierdie opsig staan die opleiding geheel en al in diens van die verkondiging.

Soos die humaniste beklemtoon ook Luther en die ander Reformatore die betekenis van Griekse en Hebreeuse taalkunde vir teologiese opleiding. Tog dien dit net as toegang tot die betekenis van Bybelse tekste. Die waarde van tale is alleen daarin geleë dat hulle ' $n$ medium van God se Woord is. Dit word duidelik uit die 
volgende uitspraak van Luther (1524:470) in sy programmatiese geskrif $A n$ die Rathsherren aller Städte Deutschlands, dass sie christliche Schulen aufrichtten und halten sollen: 'Die Sprachen sind die Scheide, darin dies Messer des Geistes steckt; sie sind der Schrein, darin man dies Kleinod trägt; sie sind das Gefäss, darin man diesem Trank fasset...' Ook die bestudering van antieke filosofie en selfs ander godsdienste soos die Islam en hulle heilige Boek, die Koran, sou die kennis van die Christendom bevorder. In kort: Die wetenskappe staan in diens van die verstaan van die Christelike boodskap, en het geen inherente waarde nie. Die mens is ook op akademiese vlak godsdienstig gegrondves.

Die Lutherse hermeneutiek het ook daartoe gelei dat die dogmatiek of sistematiese teologie ten volle eers sekondèr as 'n eie teologiese vakgebied ontwikkel het. God bly vir ons volgens Luther in beginsel onbekend, 'n deus absconditus. Gevolglik het Luther, in teenstelling tot Melanchthon se loci communis, en in teenstelling tot alle ander Reformatore, enige sistematisering van die Christelike geloof afgewys. 'n Sistematisering neig uit die aard van die saak daartoe dat die konfrontasie met die Bybel vermy of as onnodig geag word. Die mens vind maklik op dié manier gemoedsrus in 'n eie skepping en nie in die geloof in die onbekende God nie. As gevolg van hierdie teologiese redes kom die teologie van Luther dikwels baie onsistematies en op die oog af selfs chaoties en teenstrydig voor. So het Luther byvoorbeeld nooit 'n koherente Christologie ontwikkel nie (Ratschow 1982:21-37). Hierdie akademiese gaping is wel gou deur die werk van ander Reformatore aangevul, veral deur die omvattende Institutio van Calvyn, sonder om die prioriteit wat tot vandag aan die bestudering van die Bybel toegeken word, aan te tas.

Die bemiddeling van die boodskap van die Bybel en daarmee van God se heil, veronderstel aan die kant van die predikant sowél deeglike kennis en weldeurdagte begrip, as persoonlike eksistensiële betrokkenheid, want godsdienstige bemiddeling is altyd ook getuienis. Die nuwe vormgewing van teologiese opleiding tydens die Reformasie het al hierdie behoeftes in ag geneem en met mekaar verbind. Veral Melanchthon het die intellektuele begrip beklemtoon waarsonder die kennis op sigself nutteloos is. 'n Mens kan maar net leer wat hy weet en verstaan. Om dit in te oefen, het Melanchthon in Wittenberg die ou gebruik van openbare disputationes tussen professore en studente asook die ou gebruik van declamationes deur studente, heringestel (Meinhold 1960:32).

Aan die universiteite is gehalteonderrig as vereiste gestel, selfs al het dit beteken dat die getal studente verminder moes word. Net die beste skoliere behoort volgens Luther en sy medestryders na 'n universiteit te gaan. Hy verwys in sy geskrif An den christlichen Adel deutscher Nation von des christlichen Standes Besserung uit die jaar 1520 hierna wanneer hy kla oor toestande: '...[D]a man nur fragt nach der Menge, und ein jeder will einen Doctor haben' (Luther 1520a:34 If). 
Luther het teologiese opleiding ten diepste as 'n eksistensiële betrokkenheid van die student, en nie as 'n suiwer akademies-intellektuele aangeleentheid nie, verstaan. In die Vorrede vir sy Duitse boeke van 1539 haal hy Hiëronimus effektief aan met die slagspreuk: 'Oratio, meditatio, tentatio' (Luther 1539:436). Veral die tentatio, die aanvegting maak, volgens Luther, eintlik van iemand 'n teoloog wanneer hy dit moet deurmaak: 'Durch Leben, ja durch Sterben und Verdammnis wird jemand ein Theologe, nicht durch Verstehen, Lesen oder speculando' (Luther 1521:455). So is die teologiese studie soms 'n pynlike proses van geestelike groei en rypwording wat met die akademiese werk moet saamgaan. Die tentatio continua, wat van die duiwel uitgaan, dryf die teoloog daartoe om die Bybel te bestudeer en sy hele lewe deur vol te hou met studie (Luther 1521:1906). Die Lutherse belydenis ken uit die aard van die saak geen geloofsekerheid of certitudo nie.

\section{NUWE VERWAGTINGE AAN POPUI ERE OPLEIDING}

Die taak om die Woord te bemiddel, hang natuurlik baie af van die begrip van diegene wat daarna luister. Dit is moeiliker om die Bybel aan ' $n$ gemeente te verduidelik wat nie kan lees nie, as aan een wat in 'n sekere mate die Bybel self kan hanteer. Gevolglik het die Reformatore daarna gestreef om ook aan die bevolking 'n basiese teologiese opleiding te gee. Christelike ouers word herhaaldelik deur die Reformatore en owerhede vermaan om hulle kinders skool toe te stuur. Kenmerkend vir die geestelike dimensie dárvan, is dat Luther (1530:422vv) die betrokke geskrifte juis in verband met die interpretasie van die vierde gebod geskryf het. Luther verstaan selfs die vinnige ontwikkeling van skole en die wetenskappe as 'n bron van geloof en heil en gevolglik as 'n belangrike deel van die Reformasie. Hy haal onder meer die volgende spreuk aan: 'Non minus est negligere scholarem, quam corrumpere virginem' (Luther 1530:458). Toe Keiser Karel die Vyfde in die Jaar 1533 'n algemene concilium wil byeenroep, antwoord Luther dat 'n enkele predikant vir die kerk meer kan beteken as 'n hele concilium. Skole, en nie concilia nie, is die voedingsbodem van die kerk. Onvermoeid en met groot sukses het die Reformatore hulle vir die stigting van skole en universiteite beywer. Johannes Bugenhagen, vanweë sy herkoms uit Pommern in die Ooste van Duitsland ook as $d r$ Pommer of Pomeranus bekend, het met sy reise deur Europa gewoonlik in elke dorpie ten minste 'n elementère skool gestig. Die skole het ook die akademiese funksies van die ou kloosters norgeneem, alhoewel raakgesien moet word dat die kloosters tot vandag toe sentra van navorsing en geleerdheid gebly het. 
Tog was die konkrete verwagtings redelik beskeie. Luther het ouers aangeraai om dogtertjies en seuntjies ten minste een uur elke dag skool toe te stuur, sodat hulle die res van die tyd nog kan speel en huiswerk doen (Luther 1524:479). In sy geskrif teen die Turke kla Luther dat ouers hulle kinders gewoonlik nie skool toe stuur nie, en dat die kinders as gevolg daarvan noodsaaklike Christelike toerusting ontbeer (Luther 1529a:2135). Luther het reeds 'n skoolorde met drie standaarde, altesaam omtrent ses jaar, aanbeveel (kyk Walch 1892:2309f se samevatting).

\section{REFORMATORIESE TEOLOGIESE OPLEIDING VANDAG}

Teologiese opleiding is ' $n$ openbare aangeleentheid in 'n Christelike staat en daarom 'n verantwoordelikheid van die owerhede. Soos die wetenskap berus die hele kultuur op die teologiese en dit beteken uiteindelik Bybelse basis. Vanweë hierdie hoë verantwoordelikheid van opleiding moet die orde van die universiteite onder alle omstandighede gerespekteer word. So kla Luther (1520b:278-281) in die jaar 1519, in 'n brief aan Spalatin, dat die rektor van die universiteit nie genoeg gedoen het om onrus onder die studente teë te gaan nie.

Die teologiese en historiese agtergrond van die Reformasie het betrekking ook vir ons eie toekoms in Suid Afrika. Net soos tydens die Reformasie het die vraag na die heil van die mens vandag weer problematies geword. Antwoorde word nie meer uitsluitlik by die kerke of godsdienste gesoek nie, maar uiteenlopende soteriologiese - insluitend politieke - konsepte kompeteer met mekaar. Omdat antwoorde nie meer in die eerste plek in die godsdiens gesoek word nie, verloor ons kultuur (insluitende die wetenskappe) die eie oorspronklike godsdienstige basis wat sedert die Reformasie op die bestudering en bemiddeling van die Bybel gebou is. Verskynsels soos die geweldige betekenis van politieke en ander sekulêre ideologieë, die toenemende materialistiese gesindheid van mense, die ontstaan van nuwe sektes en selfs godsdienste, dui reeds op 'n soort religieuse vakuum. In Europa is hierdie ontwikkeling, wat voortgevloei het uit die Aufklărung en sy krisis (Horkheimer \& Adorno 1985:7-41) nog duideliker. Die ander wetenskappe bevraagteken nou soms selfs die wetenskaplike bestaansreg van die teologie, oorspronklik die diensmaagd van die teologie. Met ander woorde: Die kultuur is nie meer godsdienstig gegrondves nie.

Dit is te verstane dat kerke dikwels probeer om hulle bestaansreg deur middel van sekondère, dit wil sê geleende funksies soos politieke relevansie, te verdedig. Uiteindelik word die geloof daarmee 'n funksie in diens van aansprake en waardes wat die Christendom in diens neem of eintlik oorbodig maak. Dit keer die teologie van die Reformasie uiteindelik onderstebo. Tydens die Reformasie het dit wesenlik oor die verlossing, nie oor die verbetering van die wèreld nie, gegaan. Vandag hoef die kerk nie met minder tevrede te wees nie. 
In die lig van die Reformasie sal die teologie as wetenskap en die daaraan gekoppelde opleiding of verdwyn of 'n positiewe alternatief moet formuleer teenoor andere religieuse of sekulêre soteriologiese aansprake. Dit moet die aanspraak op die kultuurvormende betekenis van teologie en kerk volhou, of plek maak vir 'n nuwe siening oor menslike heil.

Omdat die gesag van die Bybelse waarheid nie meer vanselfsprekend is nie, moet elke predikant vandag, anders as in die tyd van Luther, eintlik ook 'n apologeet wees. Hy moet die Bybel ad hominem toeganklik maak en die gemeente in staat stel om self te oordeel. Daarom moet die teologiese opleiding meer as ooit tevore ook 'n studium generale wees - maar steeds teologie bly en nie verword tot vermomde en verdoeseide sosiologie, sielkunde, politiek ensovoorts nie. Die predikant moet daarmee ook ' $n$ bemiddelaar van die teologiese wetenskap aan die gemeente wees - maar ook vice versa. Luther (1527:207) vergelyk tereg nuttelose debatte tussen teoloë wat nie bydra tot die diens in die gemeente nie met die gebeure by die toring van Babel. Net soos tydens die Reformasie word die predikant gedwing om die oorspronklike gesag van die Bybelse Woord weer tot sy reg te laat kom - 'n taak wat deeglike teologiese studies vereis en wat behoort te lei tot groter onafhanklikheid van teologies-kerklike tradisies.

Volgens die Reformasie is die wetenskap van die verkondiging van die heil van die wêreld die fondament van enige verdere menslike aktiwiteit binne en buite die universiteit. Die Reformasie het dit in die Bybel gevind. Hierdie relevansie word deur teologiese en kerklike foute en misbruike net so min opgehef as tydens die Reformasie.

Menslik gesproke, sal die toekoms van die Westerse kultuur in Suid-Afrika daarvan afhang in watter mate veral die teologiese opleiding voldoen aan die eise wat die Reformasie na vore gebring het. Dit is uit die aard van die saak 'n openbare taak en verantwoordelikheid, want dit het betrekking op die diepste wortel van menslike kultuur, nạamlik die soteriologiese en daarmee ten diepste godsdienstige betrokkenheid van die mens. Om dit nie meer wetenskaplik te beoefen nie, sou beteken om die mense en die beskawing in Suid-Afrika van sy historiese fondament te beroof. Daar bestaan nie iets soos 'n natuurreservaat vir die Christendom nie.

\section{I iteratuurverwysings}

Aland, K 1982. Geschichte der Chnstenheit, II. Gütersloh: Mohn.

Campenhausen, Frhr von A 1983. Die Klöster in Niedersachsen in Luther 82. Mitreilungen aus dem Lutherjahr 1983 in Niedersachsen, Heft 1. Braunschweig: Waisenhaus-Buchdruckerei und Verlag. 
Evangelisch-Lutherschen Kirche 1979. Confessio Augustana 1530 in Die Bekenntnisschriften der Evangelisch-Lutherischen Kirche, 44-137. Göttingen: Vandenhoeck.

Heussi, K 1979. Kompendium der Kirchengeschichte. Tübingen: Mohr.

Horkheimer, M \& Adorno, W 1985. Dialektik der Aufklänung. Frankfurt: Fischer.

Kühn, D 1988. Ich Wolkenstein: Eine Biographie. Frankfurt: Insel.

Luther, M 1519. Wie die Priester ihren Lebenswandel führen sollen, in Walch 1892:1608-1613. (Band 10.).

- 1520a. An den christlichen Adel deutscher Nation von des christlichen Standes Besserung, in Walch 1892:266-351. (Band 10.)

- 1520b. Brief aan Spalatin, in Walch 1903:278. (Band 21a.)

- 1521. Psalmenauslegung, in Walch 1895-1896. (Band 4 \& 5.).

- 1524. An die Rathsherren aller Städte Deutschlands, da sie christliche Schule aufrichten und halten sollen, in Walch 1892:458-485. (Band 10.)

- 1526. Exodus Auslegung, in Walch 1894. (Band 3.)

- 1527. Genesis Auslegung, in Walch 1894. (Band 3.)

— 1529a. Schrift vom Krieg wider die Türken, in Walch 1890:2109-2155. (Band 20.)

- 1529b. Enchiridion. Catechismus minor D. Martinu Lutheri pro parochis et concionatoribus, in Die Bekenntnisschriften der Evangelisch-Lutherischen Kirche 1979, 501-542. Göttingen: Vandenhoeck.

- 1530. Ein Predigt oder Sermon, da man die Kinder solle zur Schule halten, in Walch 1892:422-459. (Band 10.)

- 1536-1545. Auslegung von Genesis, in Walch 1880. (Band 1.)

- 1539. Vorreden, in Walch 1898:1-482. (Band 14.)

Meinhold, P 1960. Philipp Melanchthon: Der Lehrer der Kirche. Berlin: Lutherisches Verlagshaus.

Peters, A 1981. Gesetz und Evangelium. Gütersloh: Mohn. (Handbuch Systematischer Theologie 2.)

Ratschow, C H 1982. Jesus Christus. Gütersloh: Mohn. (Handbuch Systematischer Theologie 5.)

Walch, J G 1880-1910. Dr Martin Luthers sämtliche Schiften, Band 1 bis 23. St. Louis: Concordia Publishing House. 